\title{
MONO- AND MIXED- LIGAND COMPLEXES OF Yb(III) WITH NEW $\beta$-DIKETONES
}

\author{
N. B. Ivakha ${ }^{1,2}$, O. S. Berezhnytska ${ }^{1,2^{*}}$, O. O. Rohovtsov ${ }^{1}$, N. V. Rusakova ${ }^{3}$, O. K. Trunova ${ }^{1}$
}

${ }^{1}$ V. I. Vernadsky Institute of General and Inorganic Chemistry of the Ukrainian NAS, prospekt Palladina 32/34, 03142 Kyiv, Ukraine

${ }^{2}$ National Technical University of Ukraine «Igor Sikorsky Kyiv Polytechnic Institute», prospekt Peremohy 37, 03056 Kyiv, Ukraine

${ }^{3}$ A.V. Bogatsky Physico-Chemical Institute of the Ukrainian NAS, 86, Lustdorf road, Odessa 650oo, Ukraine

e-mail:ivakhanadiia@gmail.com

New ytterbium (III) compounds with $\beta$-diketones (2,7-dimethyl-octene-1-dione-3,5 and 2,6-dimethyl-heptene-1-dione-3,5) and their derivatives with phenanthroline have been synthesized. The composition and chemical structure of the obtained complexes have been determined by several Physico-chemical investigations. It has been shown, that the $\mathrm{Yb}$ (III) ion coordinates three ligand molecules and the coordination sphere of the complexes is supplemented by two molecules of water or a molecule of phenanthroline. It has been shown that the $\mathrm{CN}$ of the ytterbium ion is 8 , the coordination polyhedron is a square antiprism, and the complex is characterized by no cubic symmetry. All synthesized compounds exhibit intense IR luminescence. The significant increase in the relative emission intensity of mixed ligand complexes is due to the additional antenna effect of the phenanthroline molecule.

Keywords: $\beta$-diketonates, complexes, ytterbium, phenanthroline, luminescent properties.

INTRODUCTION. The regular demand for new materials with useful applied characteristics primarily gives rise to the rapid development of science in the study of compounds with valuable functional properties. This trend did not bypass the development of chemistry and technology of lanthanides (Ln). Until recently, their field of their application was limited to the manufacture of pigments for glass and ceramic coatings, but today it is difficult to imagine a field of technology that would not use lanthanide compounds (including luminescent and laser materials, elements of catalytic systems, compounds used in medical practice, etc.) [1,2]. The permanent expansion of the uses of such compounds is primarily because more than half of them can not be fully replaced by other elements, and $\mathrm{Eu}, \mathrm{Dy}, \mathrm{Tm}$, and $\mathrm{Yb}$ are unique in their properties. However, the use of lanthanides in pure form is limited by some 
disadvantages [3], so the development of research on the chemistry of coordination compounds of rare earth elements (REE) comes to the fore. Probably, the most promising feature of lanthanide complexes is their ability to luminescence, as the presence of narrow emission bands characteristic of each ion can provide not only the purity of the emission color but also quite high values of REE luminescence intensity in complexes with many organic ligands. Among them, there are $\beta$-diketones, because such chelate complexes are characterized by a set of valuable properties important for practical use [4].

The least attention in modern research is devoted to lanthanide complexes that emit in the near IR region of the spectrum $(\mathrm{Nd}$ (III), Er (III), Yb (III)). Note that among the known complexes with the above metals, the $\mathrm{Yb}$ (III) ion has a higher quantum efficiency and a longer lifetime of luminescence with a wavelength of about $1000 \mathrm{~nm}[5,6]$, which is important for use in biological objects, because they are transparent in this range. Therefore, the study of $\mathrm{Yb}$ (III) complexes is of practical interest.

It is known, that the coordination number in lanthanide complexes is usually more than six, and in some cases can reach 12, so it is almost impossible to obtain coordinatively saturated complexes with branched $\beta$-diketones [7]. In this case, the coordination sphere of the lanthanide ion is supplemented by solvent molecules, which may adversely affect the final characteristics of the obtained compound. For example, it is known that the presence of water molecules in the first coordination sphere of the complex leads to the loss of a signifi- cant part of the energy for the excitation of high-frequency oscillations of -OH groups and the subsequent nonradiative relaxation. One of the ways to overcome this problem is to obtain mixed ligand complexes with neutral donor molecules with the simultaneous displacement of solvent molecules. The best known of these is 1,10-phenanthroline (Phen) because it has high absorption capacity and efficient energy transfer to the central ion. This approach allows one not only to minimize the influence of luminescence quenching molecules but also to purposefully change the final characteristics of the compound, such as solubility and thermal stability.

Despite the rather extensive experimental material accumulated for the synthesis and study of $\beta$-diketonate complexes of lanthanides, including those emitting in the IR region, many aspects remain undiscovered and need further study to establish correlations between the structure of organic ligands and properties.

Thus, taking into account the prospects of this area of research, the synthesis of $\mathrm{Yb}$ (III) coordination compounds with 2,7-dimethyl-octene-1-dione-3,5, and 2,6-dimethyl-heptene-1-dione-3,5 and mixed ligand phenanthroline complexes based on them was carried out in the work. The spectral, thermal and luminescent characteristics of the obtained compounds were studied.

EXPERIMENT AND DISCUSSION OF RESULTS. Sodium salts of $\beta$-diketones 2,7-dimethyl-octene-1-dione-3,5 and 2,6-dimethyl-heptene-1-dione-3,5 were synthesized by Kleisen condensation according to the method described in [8] (Table 1). 
Table 1. - Structural formulas and name of $\beta$-diketonate ligands.

Name
2,6-dimethyl-heptene-1-dione-3,5

The purity of the synthesized unsaturated $\beta$-diketones was determined by elemental analysis and the ${ }^{1} \mathrm{H}$ NMR method [9].

The synthesis of complexes of $\mathrm{Yb}$ (III) with dmhpd, dmod was performed by the interaction of aqueous solutions of ytterbium chloride $\left(\mathrm{YbCl}_{3} \cdot 6 \mathrm{H}_{2} \mathrm{O}\right.$, AR grade) with an aqueousethanolic solution of a sodium salt of the corresponding ligand at a molar ratio of $1: 3.5$ ( $\mathrm{pH} 8-8.5)$ at room temperature.

$$
\begin{aligned}
& \mathrm{Yb}^{3+}+3 \mathrm{NaL} \rightarrow \mathrm{YbL}_{3}+3 \mathrm{Na}^{+} \\
& \mathrm{L}=\mathrm{dmhpd}, \mathrm{dmod}
\end{aligned}
$$

The resulting precipitates of the complexes were separated from the mother liquor by centrifugation, washed five times with deionized water, and dried in a vacuum desiccator over anhydrous $\mathrm{CaCl}_{2}$. The synthesized complexes based on both $\beta$-diketones are amorphous pale yellow powders.

The synthesis of mixed ligand complexes (MLCs), in which phenanthroline was used as the second ligand, was performed in alcohol solutions at a ratio of LnL3: Phen $=1: 1$. The solutions were left for 3-5 h to establish equilibrium and to carry out the reaction of complexation. The precipitated complexes were filtered off and washed with ethanol.
$\mathrm{YbL}_{3} \cdot 2 \mathrm{H}_{2} \mathrm{O}+\mathrm{Phen} \rightarrow \mathrm{YbL}_{3} \cdot \mathrm{Phen}+2 \mathrm{H}_{2} \mathrm{O}$

$\mathrm{L}=$ dmhpd, dmod

The synthesized compounds were characterized by IR spectroscopy, diffuse reflectance spectroscopy, thermogravimetry and luminescence analysis.

The hydrate composition of the complexes and their thermal characteristics were determined by the DTA method. The thermograms were recorded on a derivatograph $\mathrm{Q}-1500^{\circ} \mathrm{D}$ of the system F. Paulik, J. Paulik, L. Erdey in the temperature range of $20-500^{\circ} \mathrm{C}$ with a heating rate of $5^{\circ} \mathrm{C} / \mathrm{min}$. in a platinum crucible in the presence of a carrier (anhydrous $\mathrm{Al}_{2} \mathrm{O}_{3}$ ).

The IR spectra were recorded on a Specord M80 spectrometer in the range of 400-4000 $\mathrm{cm}^{-1}$ in $\mathrm{KBr}$ pellets.

The diffuse reflection spectra in the range of 300-1100 nm were recorded on a UV-VIS-IR Shimadzu UV-3600 spectrophotometer.

The excitation and luminescence spectra of the solid complexes were recorded on a spectrofluorimeter Fluorolog FL 3-22, Horiba Jobin Yvon (Xe-lamp $450 \mathrm{~W}$ ) using a light filter. InGaAs (DSS-IGA020L, Electro-Optical Systems, Inc, USA) photoresistance at liquid nitrogen temperature was used as a radiation receiver for the IR region. 
Information on the composition and method of coordination of the synthesized $\beta$-diketonate complexes was obtained based on the analysis of results by IR spectroscopy and thermogravimetry. Based on the literature [10], the classification of the characteristic bands of oscillations in the IR spectrum of the studied samples was carried out (Table 2). The complexation is evidenced by the absence of intense oscillation bands at $1700-1750 \mathrm{~cm}^{-1}$, which correspond to $v(\mathrm{C}=\mathrm{O})$ of free $\beta$-diketone, and the appearance of characteristic oscillation bands in the region of higher energies in the range of $1520-1600 \mathrm{~cm}^{-1}$, which correspond to the oscillations of the one and a half bonds $v_{\mathrm{as}}(\mathrm{CC})$, $v_{s}(\mathrm{CO})$, which indicates the bidentate-cyclic coordination of ligands to the metal ion.

Also in the range of $400-600 \mathrm{~cm}^{-1}$ there is a set of bands that corresponds to a combination of valence oscillations of the $\mathrm{Yb}-\mathrm{O}$ bond and deformation oscillations of the chelate ring, and in the case of phenanthroline complexes a band corresponding to the valence oscillation of $\mathrm{Yb}-\mathrm{N}$ additionally appears. Their presence also confirms the formation of both monoligand and mixed ligand complexes.

In the region of $890-720 \mathrm{~cm}^{-1}$ there is a set of bands, among which in the spectra of mixed ligand complexes oscillation frequencies at 775 and $778 \mathrm{~cm}^{-1}$ can be distinguished, which correspond to the band of deformation oscillations of $\mathrm{CH}$ bonds of the phenanthroline fragment (free phenanthroline $-779 \mathrm{~cm}^{-1}$ ). The $v$ oscillation band of the $\mathrm{C}-\mathrm{N}$ group, which is observed for pure phenanthroline at $1560 \mathrm{~cm}^{-1}$, overlaps with the intense bands $v_{\text {as }}(C C)$, $v_{s}(C O)$, so it is not possible to identify them.

For the hydrated complexes of ytterbium with dimethylheptenedione and dimethyloctendione in the range of $3200-3600 \mathrm{~cm}^{-1}$, a wide oscillation band of $\mathrm{OH}$ groups is observed, which is due to the presence of water molecules in the complexes. In the case of phenanthroline complexes, the absence of this band proves that such complexes are anhydrous, and, consequently, the phenanthrolin molecule is coordinated to the $\mathrm{Yb}$ (III) ion.

Table 2 - Assignment of oscillation frequencies in the IR spectra of the synthesized complexes $\left(\mathrm{cm}^{-1}\right)$

\begin{tabular}{l|c|c|c|c|c|c}
\hline \hline Compound & $\begin{array}{c}v(\text { Ln-O })+ \\
\text { dchel.ring }\end{array}$ & $v(\mathrm{Ln}-\mathrm{N})$ & $v_{\text {as }}(\mathrm{CC})$ & $v_{\mathrm{s}}(\mathrm{CO})$ & $v(\mathrm{C}=\mathrm{O})$ & $v(\mathrm{C}=\mathrm{C})$ \\
\hline Nadmhd & - & - & 1565 & - & 1724 & 1655 \\
$\mathrm{Nadmod}$ & - & - & 1558 & - & 1715 & 1645 \\
$\mathrm{Yb}(\mathrm{dmhpd})_{3} \cdot 2 \mathrm{H}_{2} \mathrm{O}$ & $420,431,498,518$ & - & 1537 & 1581 & - & 1671 \\
$\mathrm{Yb}(\mathrm{dmhpd})_{3} \cdot \mathrm{Phen}$ & $418,435,481,524$ & 471 & 1545 & 1596 & - & 1670 \\
$\mathrm{Yb}(\mathrm{dmod})_{3} \cdot 2 \mathrm{H}_{2} \mathrm{O}$ & $425,445,489,514$ & - & 1541 & 1586 & - & 1669 \\
$\mathrm{Yb}(\mathrm{dmod})_{3} \cdot \mathrm{Phen}$ & $424,450,495,520$ & 469 & 1549 & 1591 & - & 1671 \\
\hline \hline
\end{tabular}


The hydrate composition and the heat resistance of the synthesized compounds were determined by a thermogravimetric analysis. The first endoeffect on thermograms appears in the range of $97-145^{\circ} \mathrm{C}$ for $\mathrm{Yb}(\mathrm{dmhpd})_{3} \cdot 2 \mathrm{H}_{2} \mathrm{O}$ and $115-158^{\circ} \mathrm{C}$ for $\mathrm{Yb}(\mathrm{dmod})_{3} \cdot 2 \mathrm{H}_{2} \mathrm{O}$, which corresponds to the dehydration of complexes, in particular to the loss of two coordinated water molecules, the weight loss is 5.5 and $5.0 \mathrm{wt} \%$ for $\mathrm{Yb}(\mathrm{dmhpd})_{3}$ and $\mathrm{Yb}(\mathrm{dmod})_{3}$, respectively, which is consistent with the theoretically calculated value. Slight exoeffect at $258^{\circ} \mathrm{C}$ for $\mathrm{Yb}$ (dmhpd) $)_{3} \cdot 2 \mathrm{H}_{2} \mathrm{O}, 260^{\circ} \mathrm{C}$ for $\mathrm{Yb}(\mathrm{dmhpd})_{3} \cdot$ Phen, $288^{\circ} \mathrm{C}$ and $269^{\circ} \mathrm{C}$ for $\mathrm{Yb}(\mathrm{dmod})_{3} \cdot 2 \mathrm{H}_{2} \mathrm{O}$ and $\mathrm{Yb}(\mathrm{dmod})_{3} \cdot$ Phen, respectively, probably corresponds to the melting point of the complexes. In the same interval, the polymerization of unsaturated $\beta$-diketonate complexes can occur without an initiator, consequently, we observe the super- position of several processes on each other.

Further increase in temperature is accompanied by a sharp increase in the rate of weight loss and exoeffects in the range of $320-455^{\circ} \mathrm{C}$, which corresponds to the decomposition of the organic part of the complexes. It should be noted that depending on the nature of the complexes (mono- and heteroligand) there may be different mechanisms of decomposition, which is due to the presence of donor molecules of phenanthroline in the molecules of heteroligand complexes. For the correct recording of thermograms in the range of $200-500^{\circ} \mathrm{C}$ it is necessary to research without access to air to reduce the probability of formation of oligomeric forms of metal complexes. Obviously, the complexes decompose to ytterbium oxide (III), the shape of the curve indicates the sublimation of the complexes during the study.

Table 3 - Thermal analysis of ytterbium complexes

\begin{tabular}{|c|c|c|c|c|c|c|c|c|}
\hline \multirow{3}{*}{ compound } & \multirow{2}{*}{\multicolumn{2}{|c|}{$\begin{array}{c}\text { Phen } \\
\Delta \mathrm{m}, \%\end{array}$}} & \multicolumn{4}{|c|}{ The process of dehydration } & \multicolumn{2}{|c|}{$\mathrm{t}_{\text {destuction }}{ }^{\circ} \mathrm{C}$} \\
\hline & & & \multirow{2}{*}{$\begin{array}{c}\mathrm{t},{ }^{\circ} \mathrm{C} / \text { thermo } \\
\text { effect }\end{array}$} & \multicolumn{2}{|c|}{$\Delta \mathrm{m}, \%$} & \multirow{2}{*}{$\mathrm{n}\left(\mathrm{H}_{2} \mathrm{O}\right)$} & \multirow{2}{*}{$\mathrm{t}_{\text {start. }}$} & \multirow{2}{*}{$t_{\text {fin. }}$} \\
\hline & calc. & found & & calc. & found & & & \\
\hline $\mathrm{Yb}(\mathrm{dmhpd})_{3} \cdot 2 \mathrm{H}_{2} \mathrm{O}$ & - & - & 145/endo & 5,4 & 5,5 & 2 & 312 & 475 \\
\hline $\mathrm{Yb}(\mathrm{dmhpd})_{3} \cdot \mathrm{Phen}$ & 22,1 & 25,8 & 89/endo & \multicolumn{2}{|c|}{ adsorbed } & - & 355 & 477 \\
\hline $\mathrm{Yb}(\mathrm{dmod})_{3} \cdot 2 \mathrm{H}_{2} \mathrm{O}$ & - & - & 152/endo & 5,1 & 5,0 & 2 & 328 & 462 \\
\hline $\mathrm{Yb}(\mathrm{dmod})_{3} \cdot$ Phen & 21,1 & 24,1 & 91/endo & adso & rbed & - & 334 & 455 \\
\hline
\end{tabular}

Thus, according to the results of thermal analysis and IR spectroscopy, it was found that the first coordination sphere of diketonate complexes $\mathrm{Yb}$ (III) includes two water molecules, which are completely replaced by a phenanthroline molecule in the case of mixed ligand compounds, and that the composition corre- sponds to the formulas $\mathrm{Yb}(\beta \text {-dik })_{3} \cdot 2 \mathrm{H}_{2} \mathrm{O}$ and $\mathrm{Yb}(\beta \text {-dik })_{3} \cdot$ Phen $(\beta$-dik $=$ dmhpd, dmod $)$.

It is known that for the organic molecules which contain unsaturated groups absorption in the near ultraviolet (200-400 nm) and visible $(400-800 \mathrm{~nm})$ regions is associated with $\pi \rightarrow \pi^{*}$ or $\mathrm{n} \rightarrow \pi *$ transitions [11]. 
Therefore, the analysis of the intensity of the bands and changes in their position in the electronic spectra in this range can be useful for the structure determination of the molecule.

In the diffuse reflection spectra (Fig. 1a) of the synthesized $\beta$-diketonates of ytterbium in the region of 200-350 nm, an extended band is observed (with maxima at $285 \mathrm{~nm}$ for $\mathrm{Yb}(\mathrm{dmhpd})_{3} \cdot 2 \mathrm{H}_{2} \mathrm{O}$ and $288 \mathrm{~nm}$ for $\mathrm{Yb}(\mathrm{dmod})_{3}$ $\cdot 2 \mathrm{H}_{2} \mathrm{O}$ ), which can be assigned to the electronic $\pi \rightarrow \pi^{*}$ transitions from the basic $\left(\mathrm{S}_{0}\right)$ to the excited state $\left(\mathrm{S}_{1}\right)$ of ligand molecules. In the case of phenanthroline derivatives of the obtained complexes, there is abroadening, splitting into two components and hypsochromic shift of this band $\left(\lambda \max =222,265 \mathrm{~nm}\right.$ and $\lambda_{\text {max }}=225$, $269 \mathrm{~nm}$ for the complexes with dmhpd and dmod, respectively), which indicates the coordination of the molecule of phenanthroline to the lanthanide ion and, consequently, the superposition of $\pi \rightarrow \pi^{\star}$ transition bands and the band of charge transfer from the ligand to the metal.

As is known, in the electronic spectra for all $\mathrm{Ln}^{3+}$ ions are characterized by the presence of strictly defined characteristic bands that correspond to the $f-f$ transitions of lanthanide ions from the ground state. It is known that the $\mathrm{Yb}^{3+}$ ion has only one multiplet term ${ }^{2} \mathrm{~F}$, which corresponds to 4 f-electrons [12].

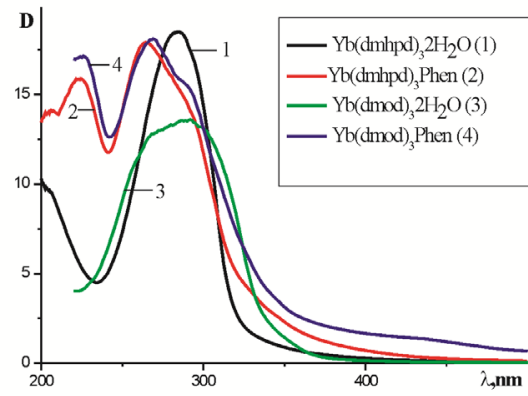

$a$

Due to the spin-orbit interaction, the components of this term ${ }^{2} \mathrm{~F}_{5 / 2}$ and ${ }^{2} \mathrm{~F}_{7 / 2}$ are distant from each other, which is manifested by the characteristic $\mathrm{Yb}^{3+}$ transitions in the near IR region of the spectrum in the range of $975-985 \mathrm{~nm}$, in the so-called «therapeutic window of tissue transparency». For $\mathrm{Yb}$ (III) complexes, we observe only one broadened split into 2 components transition with a maximum at $\sim 980 \mathrm{~nm}$. The rather wide shoulder in the region of the main transition, which is in the range of 920-930 $\mathrm{nm}$ is due to the only allowed transition for $\mathrm{Yb}$ (III), the significant emission capacity of the ytterbium ion in this coordination environment and, possibly, non-radiative processes. $\lambda_{\max }$ for the transition ${ }^{2} \mathrm{~F}_{7 / 2} \rightarrow{ }^{2} \mathrm{~F}_{5 / 2}$ of ytterbium ion in the studied samples is $971 \mathrm{~nm}\left(\mathrm{Yb}(\mathrm{dmhpd})_{3}\right.$ $\left.\cdot 2 \mathrm{H}_{2} \mathrm{O}\right), 972 \mathrm{~nm}\left(\mathrm{Yb}(\mathrm{dmod}){ }_{3} \cdot 2 \mathrm{H}_{2} \mathrm{O}\right), 974 \mathrm{~nm}$ $\left(\mathrm{Yb}(\mathrm{dmhpd})_{3} \cdot \mathrm{Phen}\right)$ and $972 \mathrm{~nm}\left(\mathrm{Yb}(\mathrm{dmod})_{3}\right.$. Phen) (Fig. 1, b). Whereas the maxima corresponding to the $\pi \rightarrow \pi *$ transitions undergo a significant shift $\left(2700-3000 \mathrm{~cm}^{-1}\right)$ upon the insertion of an additional ligand, which is due to changes in the energy state of the coordination compounds owing to the coordination of the additional molecule of phenanthroline, the line shape and maximum position of the single supersensitive transition ${ }^{2} \mathrm{~F}_{7 / 2} \rightarrow{ }^{2} \mathrm{~F}_{5 / 2}$ not only do not shift, but also do not change the shape and

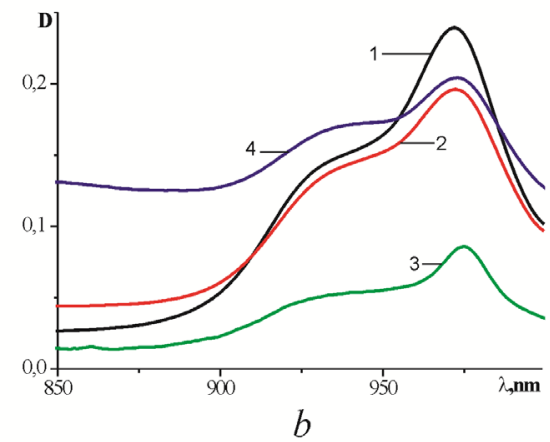

Figure 1 - SDR complex $\mathrm{Yb}(\mathrm{dmhpd})_{3} \cdot 2 \mathrm{H}_{2} \mathrm{O}, \mathrm{Yb}(\mathrm{dmhpd})_{3} \cdot \mathrm{Phen}, \mathrm{Yb}(\mathrm{dmod})_{3} \cdot 2 \mathrm{H}_{2} \mathrm{O}$ and $\mathrm{Yb}(\mathrm{d}-$ $\bmod )_{3} \cdot$ Phen. 
intensity, which indicates a similar structure of the coordination polyhedron in all synthesized coordination compounds of ytterbium.

Thus, the analysis of the diffuse reflection spectra allows us to conclude, that the structure of the coordination node does not undergo significant changes upon the formation of both mono- and mixed ligand complexes, the coordination number of the $\mathrm{Yb}^{3+}$ ion for all synthesized complexes is 8 , and the shape of the coordination polyhedron corresponds to a square antiprism, as in previously presented studies [13]. The much lower band intensity for the dimethyloctenedione-based monoligand complex can be explained by the fact that the central ion is shielded with the increasing

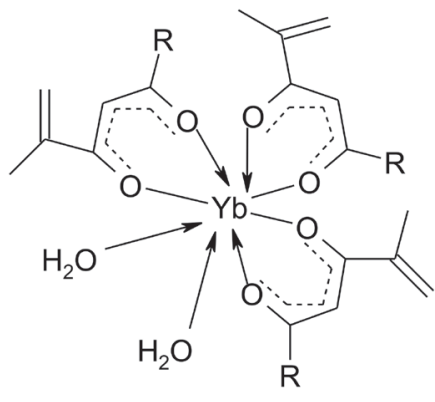

$\mathrm{R}=-\mathrm{CH}\left(\mathrm{CH}_{3}\right)_{2}(\mathbf{d m o k d}),-\mathrm{CH}\left(\mathrm{CH}_{3}\right)(\mathbf{d m h p d})$,

As noted above, $\mathrm{OH}$ oscillations significantly reduce the luminescence intensity for the elements of several lanthanides. However, it should also be noted that for the Nd (III), Er (III), and $\mathrm{Yb}$ (III) ions a significant contribution to the probability of non-radiative transition is made by the oscillations of $\mathrm{CH}$ groups, so it is important to synthesize compounds that could provide the «rigidity of the frame» of the obtained complexes and thus minimize their negative impact. In $[14,15]$ it is noted that the elements of the end of the lanthanide series (including the $\mathrm{Yb}$ (III) ion) are characterized by the forma- length of the substituent in the $\beta$-diketonate fragment. We observed a similar situation in the case of bulk phenolic substituents. Unfortunately, it is impossible to determine the correlations of this effect with IR spectra as to the length of bonds and the influence of substituents on them due to the presence in the range of $400-700 \mathrm{~cm}^{-1}$ of some oscillations characteristic not only of the $\mathrm{M}-\mathrm{O}$ bond but also of metal cycle oscillation.

Since the replacement of two molecules of water (a) by a molecule of phenanthroline (b) in the coordination sphere of complexes practically does not lead to changes in the geometry of molecule. The structure of complexes can be schematically represented as follows.



, $\mathrm{C}_{6} \mathrm{H}_{5}(\mathbf{m p h p d})$

tion of mixed ligand complexes with the most rigid coordination sphere, which, in turn, rules out the possibility of formation of several types of molecules and has a positive effect on their final characteristics. From this point of view, the synthesis of MLCs with branched ligands is also an extremely promising direction in coordination chemistry.

For lanthanide ions emitting in the IR region of the spectrum, there are to date insufficient data on the optimal value of the energy gap between the triplet levels of ligands and the emitting levels of Ln (III) ions. Accord- 
ing to Dexter's theory [16], this difference is an extremely important factor for the manifestation of effective emission, and both too large and too small gap between the energies of the ligand and the metal can lead to a decrease in radiation intensity. It is known, that the resonance level of the ion $\mathrm{Yb}$ (III) is quite low $(2 \mathrm{~F} 5 / 2-10330 \mathrm{~cm}-1)$, besides, there are no energy levels near it to which the excitation energy could be transmitted, so the determining factor, in this case, is the energy value of the triplet level of the ligand. To calculate the values of the triplet levels of dimethylheptenedione and dimethyloctenedione, gadolinium complexes were synthesized and their fluorescence and phosphorescence spectra (at $77 \mathrm{~K}$ ) were recorded. This allowed us calculating ET dmhpd $(21000 \mathrm{~cm}-1)$ and ET dmod $19350 \mathrm{~cm}$ $1)$. The energy values of the triplet levels are higher than the energy of the emitting level of the $\mathrm{Yb}(\mathrm{III})$ ion, which indicates the potential for intramolecular energy transfer to the metal ion and the ability to show effective 4 f-luminescence by such complexes.

Based on these data, a study of the luminescent properties of all synthesized monoligand and mixed ligand complexes of ytterbium with phenanthroline was performed. It is appropriate to compare theluminescent properties of the synthesized complexes with aliphatic substituents (dmhpd, dmod) and aromatic (mphpd) $[17,18]$ in the molecule of $\beta$-diketone. The emission excitation spectra of the powders (Fig. 2, a) of the synthesized complexes consist of one band split into two components with maxima $\lambda_{1 \max }=322-323 \mathrm{~nm}$ and $\lambda_{2 \max }=365-$ $367 \mathrm{~nm}$, respectively. At the same time, the excitation spectrum of $\mathrm{Yb}(\mathrm{mphpd})_{3}$ consists of a wide diffuse band with a maximum at $340 \mathrm{~nm}$. Therefore, emission spectra were recorded at different excitation wavelengths. When excited with the maximum of these bands, an intense 4f-luminescence is observed in all cases.

The emission spectra of all ytterbium complexes contain one broadened band that corresponds to the transition from the excited level of the $\mathrm{Yb}$ (III) ion ${ }^{2} \mathrm{~F}_{5 / 2} \rightarrow{ }^{2} \mathrm{~F}_{7 / 2}$ (Fig. 2, b). As can be seen from the figure, this band for $\mathrm{Yb}(\mathrm{dmhpd})_{3}$ is the most broadened and split into 3 maxima. For $\mathrm{Yb}(\mathrm{dmod})_{3}$, the emission curve is also quite wide, which allows it to be decomposed into 3 components, but the main maximum of the band is of much higher intensity. However, the relative luminescence intensity of $\mathrm{Yb}(\mathrm{mphpd})_{3}$ is 6 times lower than that of $\mathrm{Yb}(\mathrm{dmhpd})_{3}$ and 13 times lower than for $\mathrm{Yb}(\mathrm{dmod})_{3}$. The difference in the shape and relative intensity of the bands is due to the dif-


Figure 2 - Emission spectra of $\mathrm{Yb}(\mathrm{III})_{3}$ with other ligands, $\mathrm{T}=293 \mathrm{~K}, \lambda_{36}=323 \mathrm{~nm}$. 
ferent nature of the substituents in the $\beta$-diketonate fragment. The reason for the broadened lines is a decrease in the symmetry of the coordination polyhedron, the exchange interactions, and the peculiarity of the luminescence of ytterbium compounds. The coordination number remains unchanged, as evidenced by the increase in the relative intensity of luminescence. The lower luminescence intensity of the complex with aromatic substituent (mphpd) is due to the steric factor, in particular to the shielding of the emitting centers by bulky molecules. Comparing compounds with aliphatic substituents, we observe that with the increasing length of substituent per methylene group the emission intensity increases by a factor of 2 , the maximum band shifts by $2 \mathrm{~nm}$, but the shape and line width are the same, which may indicate the similar symmetry and coordination polyhedra of these complexes. Presumably, the presence of an additional $-\mathrm{CH}_{2}-$ group, due to the redistribution of electron density, weakens the bond of the $\mathrm{Yb}$ (III) ion to the ligand and, as a consequence, contributes to more efficient energy transfer from the ligand to the metal; in addition, of all calculated energies of triplet levels, $\mathrm{E}_{\text {Tdmod }}$ is lowest.

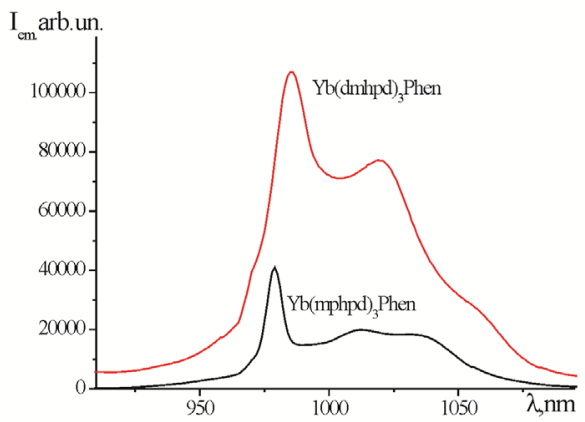

Figure 3 - Emission spectra of complexes of $\mathrm{Yb}(\mathrm{III})_{3}$ with phenantroline, $\mathrm{T}=293 \mathrm{~K}, \lambda_{36}=360 \mathrm{~nm}$.
The expected results in terms of increasing emission intensity in mixed ligand complexes came true. Comparison of the relative luminescence intensity of phenanthroline complexes (Fig. 3) showed that adding a donor molecule Phen stimulates an increase in emission intensity by a factor of 3.5 for the compounds with aliphatic substituent (dmhpd) and in 8 with aromatic substituent (mphpd), and that the position of the band shifts by $6 \mathrm{~nm}$. This is due to the steric effect, the possibility of stacking interaction of aromatic systems (phenanthroline and phenolic substituent in the ligand molecule), and the higher symmetry of methacroylacetophenoate complexes. Also, for mixed ligand complexes, we observe a narrowing of the line by a factor of 2 , which may indicate a decrease in nonradiative transitions and suggests an increase in the symmetry of the complexes (Fig. 4). The presence of two maxima in the emission excitation spectrum prompted us to record the emission spectra at different excitation wavelengths. It was established that for all mixed ligand complexes the optimal excitation wavelength is $360 \mathrm{~nm}$, at the same time for monocomplexes it is $320 \mathrm{~nm}$.

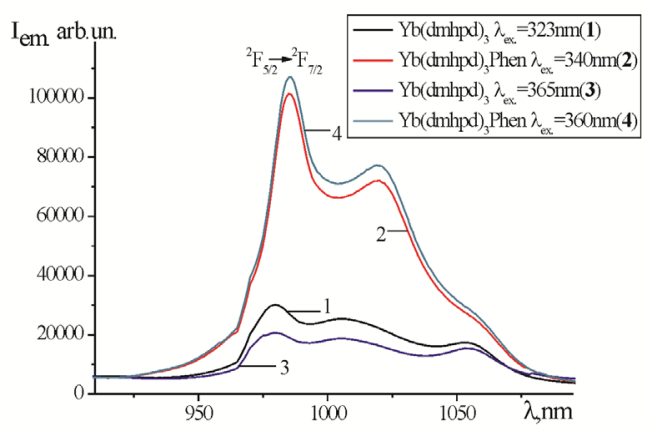

Figure 4 - Emission spectra of complexes $\mathrm{Yb}(\mathrm{dmhpd})_{3} \cdot 2 \mathrm{H}_{2} \mathrm{O}$ and $\mathrm{Yb}(\mathrm{dmhpd})_{3} \cdot \mathrm{Phen}, \mathrm{T}=293 \mathrm{~K}$ at different wavelengths of exitation. 
CONCLUSIONS. For the first time, monoand mixed-ligand complexes of ytterbium (III) based on dimethylheptene and dimethyloctenedione were synthesized in this work. The composition and structure of the synthesized complexes has been determined. It has been shown that the ligand molecules are coordinated to the central ion in a bidentate-chelate fashion. The C.N. of the central ion of ytterbium is 8 . In the case of monoligand complexes, the coordination sphere is supplemented by two molecules of water. It has been shown that all synthesized coordination compounds exhibit intense emission in the near IR region of the spectrum. The addition of the second ligand to the molecules causes an increase in the relative emission intensity, which is due to the replacement of water molecules in the near coordination environment of the central ion, which caused the quenching processes. A comparative analysis of the properties of the synthesized complexes with aliphatic substituents and complexes based on methacroylacetophenone has been performed. The highest emission intensity of the synthesized complexes based on dmod is due to the linear structure of the substituent and, accordingly, to the lack of its shielding effect, which occurs in the case of methacroylacetophenone and to the lower triplet level energy of the ligand, which reduces the energy gap between $\mathrm{E}_{\text {Tligand }}$ and $\mathrm{E}_{\mathrm{S}(\mathrm{Yb})}$, which, in turn, reduces the amount of non-radiative loss. Thus, all synthesized compounds can be used as precursors of luminescent materials.

The research was performed within the framework of departmental topics 318 E "Creation of new multifunctional nanomaterials based on coordination compounds of $3 \mathrm{~d}$-metals and lanthanides with $\mathrm{O}, \mathrm{N}$-donor ligands"
МОНО- ТА ЗМШАНОЛІГАНДН КОМПЛЕКСИ ҮЬ(III) 3 НОВИМИ $\beta$-ДИКЕТОНАМИ

Н. Б. Іваха ${ }^{1,2 \star}$, О. С. Бережницька ${ }^{1,2}$,

О. О. Роговцов ${ }^{1}$, Русакова Н. В. ${ }^{3}$, О. К. Трунова

${ }^{1}$ Інститут загальної та неорганічної хімї ім. В. I. Вернадського НАН України, просп. Академіка Палладіна, 32/34, Київ 03142, Украӥна

${ }^{2}$ Національний технічний університет Украйни "Київський політехнічний інститут" імені Ігоря Сікорського, просп. Перемоги, 37, Київ 03056, Украӥна

${ }^{3}$ Фізико-хімічний інститут ім. О. В. Богатсъкого НАН Украйни, Люстдорфська дорога, 86, Одеса 65000, Україна

e-mail:ivakhanadiia@gmail.com

У роботі синтезовано нові сполуки ітербію(III) 3 $\beta$-дикетонами (2,7-диметил-октен-1-діоном-3,5 і 2,6-диметил-гептен-1-діоном-3,5) та їхні змішанолігандні похідні 3 фенантроліном. За допомогою низки фізико-хімічних досліджень отриманих комплексів встановлено їхній склад та хімічну будову. В ІЧ-спектрах синтезованих координаційних сполук спостерігають набір смуг, який вказує на бідентатно-циклічну координацію лігандів до іону металу. Смуги в інтервалі 400-600 см-1 відповідають комбінації валетних коливань зв'язку $\mathrm{Yb}-\mathrm{O}$ та деформаційних коливань хелатного кільця, а у випадку фенантролінових комплексів додатково проявляється смуга, що відповідає валентному коливанню $\mathrm{Yb}-\mathrm{N}$. Дослідження термічної стійкості зразків дозволили встановити, що координаційна 
сфера монолігандних комплексів доповнюється двома молекулами води, які повністю витісняються молекулою фенантроліну у змішанолігандних аналогах. Форма, положення та зміщення спектральних смуг в ЕСДВ свідчить про проходження процесів комплексоутворення та одержання комплексів некубічної симетрії з к. ч. Yb (III) 8. Входження молекули фенантроліну до складу комплексів суттєво не впливає на будову координаційного вузла. Дослідження методом люмінесцентного аналізу показали, що всі одержані сполуки проявляють інтенсивну люмінесценцію в ІЧ-області спектру, причому слід зазначити, що наявність додаткової - $\mathrm{CH}_{2}$ - групи у випадку комплексів iз dmod сприяє підвищенню відносної інтенсивності емісії. Синтез змішанолігандних комплексів також збільшує ефективність випромінювання внаслідок нівелювання негативного впливу О-Н-коливань молекул води, тому всі представлені сполуки можна запропонувати як прекурсори люмінесцентних матеріалів.

Ключові слова: $\beta$-дикетонати, комплекси, ітербій, фенантролін, люмінесцентні властивості.

\section{REFERENCES}

1. Fan S., Yao X., Li J., Li W., Li G. Near-infrared luminescent materials: From $\beta$-diketonate ytterbium complexes to $\beta$-diketonate-ytterbium-complex PMMA thin film. Journal of Luminescence. 2018. 203: 473480.

2. Santos H.P., Gomes E.S., Santos M.V., D’Oliveira K.A., Cuin A., Martins J.S., Quirino W.G., Marques L.F. Synthesis, structures and spectroscopy of three new lanthanide $\beta$-diketonate complexes with 4,4'-dimethyl-2,2'-bipyridine. Near-infrared electroluminescence of ytterbium (III) complex in OLED. Inorganica Chimica Acta. 2018. doi: 10.1016/j.ica.2018.09.030.

3. Choppin G.R., Gschneidner K.A., Eyring L., Lander G.H. Lanthanides/Actinides: Physics-II, Volume 19, 1st Edition. Handbook on the Physics and Chemistry of Rare Earths. 1994. 18: 1-674.

4. Mara D., Artizzu F., Laforce B., Vincze L., Hecke K. V., Deun R. V., Kaczmarek A. M. Novel tetrakis lanthanide $\beta$-diketonate complexes: Structural study, luminescence properties and temperature sensing Journal of Luminescence. 2019. 213: 343-355.

5. Zhang X ,. Liu L., Yu C., Li H., Fu G., Lü X., Wong W.-K., Jones R.A. Highly efficient near-infrared (NIR) luminescent tris- $\beta$-diketonate $\mathrm{Yb}^{3+}$ complex in solution and in PMMA. Inorganic Chemistry Communications. 2016. 70:153-156.

6. Wang X., Zhu Q., Li J.-G., Hu Z., Zhu G., Wang C.La $\mathrm{O}_{2} \mathrm{~S}: \mathrm{Tm} / \mathrm{Yb}$ as a novel phosphor for highly pure near-infrared upconversion luminescence. Scripta Materialia. 2018. 149: 121-124. 
7. Bünzli J.-C. G. Review: Lanthanide coordination chemistry: from old concepts to coordination polymers. Journal of Coordination Chemistry, 2014. doi: 10.1080/00958972.2014.957201.

8. Berezhnytska O.S., Trunova O.K., Ivakha N.B., Savchenko I.O., Rohovtsov O.O., Gudima A.O. The method of obtaining a new nanoscale metalopolymer of Nd. Ukrainian patentfor utility model № 100305. [in Ukrainian]

9. Ivakha N.B., Berezhnytska O.S., Rohovtsov O.O., Trunova O.K. Complexes of Neodium(III) and Erbium(III) with new unsaturated $\beta$-diketones. Ukrainian Chemical Journal. 2019. 85 (6): 87-96. [in Ukrainian]

10. Nakamoto K. Infrared spectroscopy of inorganic and coordination compounds. M.: Mir.1991: 536. [in Russian]

11. Bettencourt Dias A. Lanthanides: Electronic Structure. Encyclopedia of Inorganic and Bioinorganic Chemistry. 2012. https://doi.org/10.1002/9781119951438. eibc2009.

12. Crosby G.A., Kasha M. Intramolecular energy transfer in ytterbium organic chelates. Spectrochim. Acta. 1958. 10: 377-382.

13. Ivakha N.B., Berezhnytska O.S., Trunova O.K., Rusakova N.V., Smola S.S., Zheleznova L.I. New $\beta$-dicarbonyl complexes $\mathrm{Nd}, \mathrm{Er}, \mathrm{Yb}$ emitting in the IR region.
Ukrainian Chemical Journal. 2015. 81 (12): 104-110. [in Ukrainian]

14. Zhuravlyov S., Rusakova N., Korovin Yu. $4 f$-Luminescence of ytterbium ions in the complexes with asymmetric porphyrins. Journal of Alloys and Compounds. 2008. 451 (1-2): 334-337.

15. Comby S, Bünzli J C G. Lanthanide near-infrared luminescence in molecular probes and devices. Handbook on the Physics and Chemistry of Rare Earths. Amsterdam: Elsevier Science B.V. 2007. 37: 235.

16. G.Bünzli J.-C. Lanthanide Luminescence: From a Mystery to Rationalization, Understanding, and Applications. Handbook on the Physics and Chemistry of Rare Earths. 2016. 287 (50): 141-176.

17. Ivakha N. B., Savchenko I. O., Berezhnytska O. S., Rusakova N. V., Trunova O. K. Ytterbium metal polymers as precursors of luminescent materials emitting in the near infrared region. Applied Nanoscience. 2020.

https://doi.org/10.1007/s13204-02001342-w.

18. Berezhnytska O. S., Ivakha N. B., Trunova O. K., Savchenko I. O., Rusakova N. V. The new NIR-emitting compounds based on $\beta$ - dicarbonyl ligands. Molecular Crystals and Liquid Crystals. 2018.670 (1): 2030 .

Стаття надійшла 19.03.2021. 